\title{
BEARS and TRAITORS, or: POLITICAL TENSIONS in the GRAND DUCHY, ca.1440-1481
}

\author{
Stephen C. ROWELL \\ Klaipeda University
}

If the fourteenth century in Central Europe can be characterised broadly as the age of the new or re-formed monarchies, including both Poland and Lithuania, then the fifteenth century finds many European kingdoms wrent by strong particularist tendencies, especially in peripheral districts. For Philippe de Commynes, who wrote of the Praguerie (1440), itself a French rebellion named after what was perceived as a Bohemian custom, and lived through the War of the Common Weal (1465), it was a matter of course, if admittedly also of sin, that European kingdoms should be torn by strife' .

The Jagiellonian monarchy provides yet another example of particularist tendencies in its extensive localities, where rebellions took place (with what seems to us to be alarming frequency) in defence of local rights, often with reference to the cause of an alienated Gediminid or Piast duke, whose strength or, more often, weakness was regarded as a guarantor of those (perceived) rights. Here we might bear in mind too that the English wars of the Roses were in essence a family dispute between the heirs male and heirs general of Edward III, or rather, that competition between various members of a large ruling family formed convenient pegs on which other political ambitions could be hung. For 'Edward', we would do well to read 'Gediminas'. Likewise, English political life in the fifteenth century was dominated by noble affinities. Special attention is paid to magnates and princes of the blood royal and the influence they held over king and court. That such men had material interests is perfectly clear, but it should also be borne in mind that higher ideals may also have influenced their actions ${ }^{2}$. Michael Jones's concise description of French political life in that century fits Lithuano-Polish relations very well: "in fifteenth-century France royal conceptions of sovereignty were in conflict with provincial ones" ${ }^{\prime \prime}$. The point of such comparisons is simple:

'P. de Commyncs. Memoirs. The reign of Louis XI 1461-83, tr. M. Joncs (Harmondsworth, 1972), 341 [Book 5, ch.18]: "this is the way it has to be here and everywhere clse".

${ }^{2}$ Scc The Wars of the Roses, cd. A.J. Pollard (London,1995), 9, 11, 89-133.

${ }^{3} \mathrm{M}$. Jones. " Bons Bretons et bons francoys', the language and meaning of treason in later medicval France", Transactions of the Royal Historical Society, 5th scrics, XXXII (1982), 111. 
the Grand Duchy is not so different from other European states. Lithuanian historiography has tended from the nineteenth century to categorise these rebellions as patriotic attempts to defend the Grand Duchy's independence from 'national' Poland. Thus, the reign of Vytautas (1392-1430) is portrayed as "autonomy" par excellence and the period following his death needs must mark a weakening of such "independence". The reign of Vytautas marks an end to the late fourteenth-century winters of discontent made glorious (or at least tepid) summer by the realignment of a majority of influential nobles behind Jogaila's sons by 1440-7. Lithuanian historians too must ask themselves how far can we ignore boiar self-interest or a more apparently patriotic 'national' motivation, and how the two interests gradually combined.

It is generally accepted that the political power of the Lithuanian bajorate as an estate can be traced back to the band of servitors chosen by Vytautas to assist grand-ducal administration of the territories under Lithuanian hegemony ${ }^{4}$. For all their activity, these men remained under the firm control of the grand duke on whom they depended for their authority. In local uprisings opponents of Vytautas and his "thyonen" stressed their dislike of such apparatchiki, as we see from the Teutonic Order's officers' differentiation between "bayoren" tout court and "thyonen"'. After Vytautas's death they eventually came to accept, as he had accepted, the dynastic priority of the line of Jogaila, even if some of them were inclined to twist the old king's arm in favour of Vytautas's brother, Žygimantas Kęstutaitis or his own sibling, Švitrigaila. A link running through politics in the fifteenth century is loyalty to the Jagiellonian succession and various attempts to maintain influence over the ruler of the grand duchy, be he also king of Poland or not.

The thesis under examination is this: that the rebellions of the mid-fifteenth century during the absence of a fully established royal government mark a significant step forward in the growing consolidation of a political community of lesser nobles in the Grand Duchy of Lithuania and in their affiliation with the line of Jogaila. The minority of Casimir provided a breathing gap for the ambitions of Lithuanian nobles to strengthen. It is significant that by the end of the century, the Council of Lords (ponu taryba) was well established as a legally

"E. Gudavičius. "Krévos sutartics (1385 m.) tikslai ir jo igyvendinimo galimybés", LMADA 1977:1, 67-74; I. Valikonyté. "Lictuvos Didžiosios Kunigaikštystćs ponų tarybos vaidmuo valstybiniame ir politiniame gyvenimc XV a. antrojojc pusćjc (iki $1492 \mathrm{~m}$.)", Istorija, XIII:2 (1972), 71-80.

5tivun: local administrator. Cf. the account of Žcmaitijan discontent with Vytautas in Fcbruary [1419]: Ms.: |Bcrlin, Gchcimcs Staatsarchiv, Prcussischer Kulturbcsitz, Königsberg Archiv,| OBA LS XVI.12: "in dem ganczen lande nor .XL. und hundert scyn als kemerer und thyonen, dic es mit Wytolde halden und nicht mecr ... ouch spricht her, das drcy \thyunen/ [corrected from bayoren by the scribc| der besten..." 
privileged body with self-limiting membership, rather than what simply was primarily an alliance of kin and affines, and that nobles were willing at last to contemplate revolts against the ruler as unacceptable blows against 'Lithuania' and themselves (in unison with the monarch). Here we will survey major outbreaks of unrest in the Grand Duchy from the murder of Žygimantas to the Kievan conspiracy of 1481. In an appendix we will assess briefly Žygimantas's reign and note the development of a 'bad ruler' exemplar which reflects growing discontent with political violence during the late fifteenth and early sixteenth centuries.

On Palm Sunday, March 20 1440, Grand Duke Žygimantas Kčstutaitis was murdered in Trakai by his cousin, Prince Ivan Czartorysky in collusion with unnamed leaders of Žygimantas's administration, who, according to Długosz, feared the wrath of their ruler ${ }^{6}$. The Rus'ian chronicle contemporary with these events is not verbose, but its main conclusion, that Zygimantas's successor, Casimir, was installed "tikho i bezmiatezhno", seems to be accurate ${ }^{7}$. The Lithuanian nobility divided subsequently into several groupings, each favouring a different dynastic solution to the problem of who was to govern the Grand Duchy ${ }^{8}$. The group which came to prominence was dominated not by disgruntled princes (these seem to have lain low) or the 'old' aristocracy (Giedraičiai and such like), nor by the kin of the dead ruler and the sons of his cousin Jogaila, but by the southern Lithuanian lords and their allies/kin who had been prominent in the 1430s and consistently active in discussions of Jagiellonian rights to rule. This group, consisting of affines and former servants of Grand Duke Vytautas and, exceptionally, of close kin of the dowager Queen-grand duchess, Sofia Alšẻniškytè, included Bishop Matthias of Vilnius, Jonas Goštautas, Astik-Radvilas, Andrius Davainaitis, Mantvydas and Petras Mantigirdas. There seems to have been a remarkable consensus among all levels of the nobility, even if some areas (parts of Žemaitija, Smolensk, Grodno and the like) were unsure whom to support - for a while. According to Długosz, Casimir was welcomed to Lithuania in June 1440 by Olelka of Kiev (a paternal cousin), Jurgis Simonaitis

Iounnis Dlugossii seu Longini canonici Cracoviensis Historiae Polonicae libri XII, cd. I. Polkowski and Żcgota Pauli, IV (Kraków,1877) |Długosz IV], 651-9; Polnoe Sobranie Russkikh Letopisei |PSRL|XXXV (Moscow,1980), 109; the Bychowicc chronicler namcs the starosta of Trakai, Leliuša as one of the main conspirators - PSRL XXXII (Moscow, 1975), 156. For a critical analysis of the various chronicle records for this cvent, sce K. Chodynicki, "Gcncza i rozwój podania o zabójstwic Zygmunta Kicjstutowicza (Zc studiów nad dzicjopisarstwem litcwskim)", Ateneum wileńskie V:15 (1928), 79-103. The conclusion drawn tentatively in B. Dundulis. Lietuvos kova dèl valstybinio savarankiškumo XV amžiuje (Vilnius, 1993), 172, that support for the lower orders and collaboration with Poland led to the grand duke's downfall, is not grounded in the sources - sce below, p. 16.

${ }^{7}$ Novgorod First Chronicle, PSRL IV (St Petcrsburg, 1841), 113.

${ }^{8} J$. Dlugosz. IV, 621. 
[Alšéniškis] (a maternal uncle), the dukes Putiata (Drutsky, a cousin of Casimir's mother), Teodoras Kaributaitis, and nobles including Senko Gedygaudas in addition to those already noted". The Alšeniškis connection is of paramount importance. It provides a connection to keep the old princes at bay and a narrow gate for the Goštautai to enter now into Jagiellonian (as opposed to Kęstutid) government circles. Casimir's relations with Sofia and her retinue (members of which accompanied Casimir to Lithuania from Poland) were maintained during the rest of the queen's life. In effect the maintenance of the union with Jagiellonian Poland was accepted and the line of Jogaila recognised as the best guarantor of Lithuanian boiar privilege.

The coup d'état was carried out very smoothly - indeed, tikho. The Czartoryskis were not punished (indeed, they were rewarded in 1442 with recognition of their kinship with the ruling Gediminids ${ }^{10}$ ) and faded back to their natural place beside Švitrigaila, others of whose supporters (such as Putiata) also exhibited their loyalty to Casimir. The grand-ducal officers continued to govern as before - the only major change was Goštautas's appointment as wojewoda of Trakai in place of Leliuša, who nonetheless kept his life and official favour. The archdeacon of Vilnius and functionary, Martinus de Schadek, who had been favoured by Žygimantas served Casimir well. It seems too that the grand-ducal secretary, Mikołaj of Błaskowice also served Casimir in the first years of his reign. The earliest charters issued by the new grand duke were witnessed by the same men who appear in Żyimantas's texts ${ }^{11}$.

The minority of Casimir IV as grand duke of Lithuania was to provide a period of controlled chaos, allowing a series of political groupings to form and consolidate. If the nobility was divided in 1440 primarily along lines of kin and friendship, by 1492 its cliques were

\section{"J. Długosz. IV, 621, 655.}

"J. Tęgowski. "Ktory Konstanty - Olgicrdowić czy Koriatowić - był przodkicm kniazów czartoryskich?”, Europa Orientalis. Polska $i$ jej wschodni squsiedzi od średniowiecza po wspótczesnosść. (Toruń,1996), 58 and n. 25, citing the original ms in the Czartoryski Library (Perg. nr Depozyt 1).

"Martinus de Schadek, archdeacon of Vilnius, "a longo tempore Lithuanicis consiliis interessc solitus" (Długosz V, 22): in Žygimantas's scrvicc - J. Długosz IV, 542 (1434), LivEst-und Curländisches Urkundenhuch nebst Regesten, $|L U|$ cd. F. G. von Bungc VIII (RigaMoscow, 1884), No.986, p. 597; in Casimir's scrvicc - Kodeks dyplomatyczny katedry $i$ diecezji wilenskiej $\mid K D K D W\rceil$, cd. J. Fijałck and W. Scmkowicz. I (Kraków,1948), No.166, p.188-9, LU X, Nos. 17(), 171, pp.108-16 and Długosz V, 6; Mikołaj appcars in Žygimantas's documents of 1432-37: Codex epistolaris saeculi decimi quinti $\mid$ CESXV], cd. A. Lewicki. III (Kraków,1894), App. No. 22, pp.529-31, Akty Litovskoi Metriki, cd. Th.I. Lcontovich. I.1 (1413-1498 gg) (Warsaw, 1896), No.6; J. Wolff. Senatorowie i dygnitarze Wielkiego Księstwa Litewskiego 1386-1795 (Kraków, 1885), 253, notes that he later became bishop of Pzcmysl; in the carly ycars of Casimir's reign mention is madc of a secretary named Mikołaj-KDKDW, Nos. 170 (18.03.42), 178 (08.04.44), pp.193, 204. The witncss lists for documents from the $1430 \mathrm{~s}$ and carly 144 ()s arc remarkably similar. 
defined more clearly in law ${ }^{12}$. It should be noted that the development of such social divisions was not peculiar to Lithuania. The Teutonic Order in Prussia, which might have been expected to make much of the division in the Jagiellonian lands, was faced from March 20, 1440 with the Prussian Union and even earlier with accusations of tyrannical behaviour where the Knights are compared with the Cyclops ${ }^{13}$. Understandably it was loth to provoke Polish interference. In Poland the duchies were divided by conflicting interests: the Little Polish nobility continued to dominate royal politics under Oleśnicki's guidance, but the Great Poles, whose representatives formed the greater part of the queen's retinue, looked northwards and in Silesia rebellion in favour of the local Piast dukes was a frequent occurrence.

On June 291440 Casimir was welcomed in Vilnius by his supporters ${ }^{14}$. Casimir was chosen as grand duke and as such gained his brother's approval. On June 6 Švitrigaila had sworn loyalty already to Jogaila's sons ${ }^{15}$. In January 1441 Casimir felt confident enough of his position to inform the Order that he had been elevated to the Grand Duchy as 'verus heres in sede paterna', ruling in Lithuania, Žemaitija and Russia ${ }^{16}$. Practical government was in the hands of a southern Lithuanian noble junta headed by Jonas Goštautas ${ }^{17}$. The "lesser" nobility ("non-southern" might be a more accurate description of them than Długosz's term), especially that of Žemaitija, however, having been favoured by Žygimantas, lent their support to his son, Mykola, and within three weeks of Casimir's proud announcement, the Livonian master noted continuing unrest in Smolensk in support of a kindred competitor, Jury Lengvenaitis ${ }^{18}$. However, Casimir's supporters suppressed the rebellion in Smolensk and Lengvenaitis withdrew to Mos-

${ }^{12}$ Privilege of Alcksander Jagicllończyk, Aug. 6 1492: M.K. Liubavskii. Ocherk istorii litovsko-russkogo gosudarstva do Liublinskoi unii vkliuchitel'no (Moscow, 191522), 328-34. Our intention here is not to assess the rights imbucd in this body but to sec the milicu out of which potential counscllors arosc.

${ }^{13}$ Titius. Prussia a tyrannide cruciferorum liberata citcd in 1. Daniłowicz. Skarbiec diplomatów papiezkich, cesarskich..., II (Vilnius, 1862), No. 1761, p.172 s.a. 1438.

14 "Kazimirus rex Polonic in locum huius succedit ct susceptus est in magnum ducem Lithphanic ipso dic bcatorum Pctri ct Pauli appostolorum", Zdarzenia godne pamięci, Monumenta Poloniae Historica III, 312.

${ }^{15}$ In 1441 Wladysław of Poland/Hungary stylcd himsclf "Wladislaus Dei gracia Hungaric, Polonic, Dalmacic, Croacic ctc Rex, Lithwanicque princeps supremus ct heres Russic" (02.06.41): Knigi pol'skoi koronnoi metriki XV stoletia, I, Kniga No.10, 1447-1454 (Warsaw, 1914), No.10, p.9. Švitrigaila's allcgiance to Władysław, ()6.06.1440-CESXV, cd. A. Sokołowski and J. Szujski. I.1 (Kraków,1876), No. 113, p.122-3.

${ }^{16}$ Sec Casimir's letter to Paul v. Russdorf, dated Jan.1 1441, concerning mercantile privileges for Vilnius and Kaunas - MS LVIA F1135 No.4 g. 25, pp.445-7, No.439; publishod in Hansisches Urkundenhuch VII (Wcimar,1939) Nr.644.

${ }^{17}$ The carlicst commercial agrecments and land charters of Casimir's reign were issucd "ad mandatum magnifici Gastoldi".

${ }^{18}$ Livonian master to the Grand Master, Jan.18, 1441 - LU IX (Riga-Moscow, 1889, repr. Aalcn,1981) No. 684, p.481. 
cow, lending support to Mykola's candidature. By the end of February Casimir was writing to the grand master asking him to arrest the starosta of Žemaitija should the latter pass through Order territory [en route to Mazovia to parley with Mykola $]^{14}$. It is not clear who this starosta was, for he is not named, even though he is described somewhat vaguely by Casimir as "eyn sulch heyde und echter [feind] des heiligen gelobens". If we follow only the available documentary evidence, this starosta was Kantautas, whom Žygimantas had appointed to replace Kęsgaila in the wake of the latter's involvement in the 1432 conspiracy against Kęstutaitis ${ }^{20}$. Kantautas held land in Kražiai, Laukuva, Knetuva and surrounding districts ${ }^{21}$. He was granted vacant lands near the border with Prussia (at Laukuva and Palanga) in his capacity as starosta 22 . Presumably he was one of the "lesser" boiars favoured by Žygimantas. In comparison with the lands held to the north by Kęsgaila, it would seem that Kantautas held sway in the more western-central reaches of Žemaitija. It seems that in April 1441 Kantautas was confirming land grants made during the reign of Žygimantas ${ }^{23}$. Some time during the late summer of 1441, during Władysław III's siege of Kassa, the Commander of Soldau reported that Casimir was very unpopular with the Lithuanian nobility and even that he had been defeated by the Žemaičiai (or certain of them) in battle:

${ }^{10} L i v o n i a n$ Master to Stadholder of Memcl, Fch.27, 1441: OBA 7923; copy: LVIA F11.35/4/25 No.44(), pp.449-5(): published in full in S.C. Rowcll. "Išdavystè ar paprasti nesutarimai? Kazimicras Jogailaitis ir Lictuvos diduomenc, 1440-1481 m.", Lietuvos valstybe XIII-XVIII a., cd. Z. Kiaupa (Vilnius, 1997). Appendix 1, pp.19-20) and O. Halccki. "Litwa, Rus i Żmudź jako czçści składowe Wiclkicgo Ksiçstwa Litewskicgo", Rozprawy hist-filoz. Akademii Umiejętności w Krakowie 69 (1916), 243-4.

2"L|ietuvos| M|etrika (1528-1547), |6|-oji Teismu bylu knyga|(Vilnius,1995), Nos.398 p. 269; 417,ii p.277 ctc. K. Pictkicwicz, Kieźgajtowie $i$ ich latyfundium do polowy XVI wieku. Ze studiów nad rozwojem wlasności ziemskiej w Wielkim Księstwie Litewskim w Średniowieczu (Poznań,1982), 21-2 and n.68. Bychowice has given risc to another tradition, according to which Kesgaila returned to office for six months before being replaced by Daumantas. brother of Kontautas - O. Halecki. "Litwa, Ruś i Żmudź", 248 and R. Jasas's commentary in Lietuvos metraštis, Bychovco kronika (Vilnius, 1971), 29(),291. M. Stryjkowski (Kronika polska, litewska, źmódzka i wszystkiej Rusi II |Warsaw,1846, rcpr.1985|, 208-209) considcred that this kontowtow was Daumantas Gicdraitis or another man - in the 16th century this person (if, not invented) was uncertain.

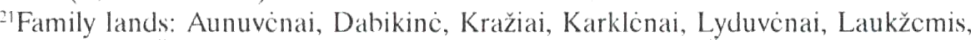
Pajūris (Tauragè), Šaunenai, Tytuvénai: V. Vaivada, Reformacija Žemaitijoje XVI a. II-je puseje |Unpublished ph.d. disscrtation, University of Vilnius, 1994| Table 5, Kontautas lands in the sixtcenth century.

${ }^{2}$ Panu Kontovtu zemlia pustaia Lovkova na nemetskom" rubezhi, a nasledka dei nct". A data u Vil'ni, maia 3, in"dik 14. Mikh. kan. Mikit. - D [okumenty] M|oskovskogo| A|rkhiva| M|inisterstva| Iu|stitsii|, I, (Moscow, 1897), 37.1(; Panu Kontovtu u Knctonskoi volosti liud Ovniane 30 i chotyri choloveki ... A v Krozhcl.h ... To vsikh liudci dano panu Kontovtu 50 cholovckov" kunichnikov. Pan" Dov"kgirl" a pan" Kgastovt". - ihid. 39.8; 39.7

${ }^{23} L M 6, \mathrm{~N}(0.417$, p. 277 
"so hat er [eyn gutfrunde uss Palan] mir gesaget, wie her vornomen habe von Lytten wie

sich die Lytten mit dem Samayten geslagen haben unde die Samayten das felt haben

behalden, unde ab ichtis wirhafftigss daran seyn, dass kan her mir war nicht sagen,

sunder er spricht wie is dem jungen konige nich alczu gerade gehee mit senen sachen

\section{in Lytten" $"$.}

In the early autumn of 1441 (around Sept. 17) Casimir - and here, as elsewhere, we should bear in mind that 'Casimir' is often a cipher for 'Goštautas' - sent Mantigaila, a creature of Vytautas, as his plenipotentiary to treat with the Žemaičiai ${ }^{25}$. At around the same time he made overtures to the Livonian and Prussian branches of the Order, asking for friendship during the period of revolt ${ }^{26}$. Casimir offered the Žemaičiai the same conditions as Vytautas and Jogaila had granted them. In return for Casimir's agreement not to send a starosta from Lithuania, the Žemaičiai expressed a willingness to sacrifice Kantautas, Byrgal his brother Byklis and Dovjatis and two other officers from the local regime in return for Gedegaudas, i.e. a Vytautas man of known good service to Žemaitija (from the embassy sent to the Council of Constance), and also a supporter of Casimir ${ }^{27}$. Meanwhile, Kantautas had sent four envoys to Mykola; these Mantigaila tried to stop in Palanga ${ }^{2 *}$. During the Parczew seim of October 2, Mazovian pretensions to grand-ducal office increased and it seems that extra pressure was placed on all parties by the king's, Władysław's, consideration of plans to partition the Grand Duchy ${ }^{21}$. In the meantime, the "rebellious" Žemaičiai and the Teutonic Order continued trading ${ }^{3(1)}$.

${ }^{24} \mathrm{Ms}$.:OBA 8(133, publishcd in full in S.C. Rowcll, "Karas ruscno) Žcmaičiuosc. Kclctas pastabụ dèl 1442 m. privilegijos genczès", Žemaičiu prueitis (Vilnius, forthcoming), app. 3. Citcd in L. Kolankowski. Dzieje Wielkiego Księstwa Litewskiego (Warsaw, 1930), 233. That a battle took place is noted by Casimir's cnvoy to the Grand Master on July 25-26 1442, Andrius Davainaitis: OF 15 p.147-50, published Rowell, "Išdavystè", appendix 3, p.23.

2i"her Montegal cynen Ritter wedder ken Zamayten gesant mit scynen macht bricfen als hewte vicrtezen tage vorgangen", Oct. 11441 - OBA 7994 and O. Halccki. "Litwa, Rus iŻmudź", 243-4 n.5 and S. C. Rowvell. "Išdavystè", app. 2, p.22.

${ }^{26}$ Ibid., 21.

${ }^{27}$ Gedegaudienc refers to herself as Gedegaudas' widow in a donation to Vilnius Cathedral on September 30 $1442-K D K D W$, No. 173, p.196-7. Henec his death before this date. Sec also W. Peltz, "Ród Gicdygolda i jego majętności", Zeszyty Naukowe UAM: Historia XI (1971), 23-44. According to the record of land granted by Casimir and/or the Ponai, one of these men, Daujotis, held land in Rasciniai and Žicžmariai (DMAMIu, p. 27,38,6())

${ }^{28}$ As n. 19 .

${ }^{29} J$. Długosz. IV, p. 6583() OBA Register 7 - OF 15, p. 147-50, published in full: S. C. Rowcll, "Išdavystè", app. 3, pp.22-25.

"OBA Register 7 - OF 15, p. 147-50, published in full: S. C. Rowcll, "Išdavystè", app. 3, pp. 22-25. 
Before the end of February 1442, the 'grand duke granted Žemaitija a charter in keeping with terms outlined in Mantigaila's mission: that conditions established by Vytautas and the old king will be maintained; officials will not be sent into Žemaitija from Lithuania and the grand duke will appoint whomever the Žemaičiai choose as tivun ${ }^{31}$. It seems that Kęsgaila returned to office as obirster hauptmann and that Kantautas remained as hauptman, perhaps serving the function of palliative to the divisions in local society which made Kęsgaila's return to sole power difficult, as may be indicated by the Bychowiec chronicler's reference to Kęsgaila as starosta during part of 1440-41, a reassumption of power (with his kinman Goštautas' help) during the rebellion. In Žemaitija unrest continued in some districts. In 1442 and 1443 Duke Mykola was still sending men into Žemaitija/ the Grand Duchy much to the grand duke's (or Goštautas's) annoyance ${ }^{32}$. The situation was far from as cut and dried as the Bychowiec chronicler (sponsored by Albertas Goštautas) would have us believe. Nevertheless, by early 1442 Casimir's party had gained nominal control (at least) of the major commercial props of the Grand Duchy: Smolensk and Polotsk in eastern Rus', Žemaitija and Grodno-Brest.

Goštautas in Vilnius supported his fellow old timer and probable affine, Kęsgaila ${ }^{33}$. The revolt against Casimir, or rather, the administration led by Goštautas, his protector, lasted a year or more, involving armed conflict and attempts to draw Mykola Žygimantaitis back from exile in Mazovia via Prussia. The solution is a Lithuanian compromise: both Kantautas and Kčsgaila retained rank as starosta, although Kęsgaila gained the added soubriquet of obirster. In 1448 Kantautas asked Casimir to grant land to his man Eitutis, and five years later, as a letter from the Commander of Memel reveals, he still bore the title of starosta of Žemaitija tout court $^{34}$. Žemaitija gained

"Zhiór praw litewskich (Poznań,1841), 67-72; K. Jablonskis. "Archivinés smulkmenos", Praeitis II (1930), 423-4; Lietuvos TSR istorijos šaltiniai I (Vilnius, 1955) No. 194, p.157. For a discussion of the versions of this text whose original is no longer extant sec $\mathrm{S}$. C. Rowell, "Karas ruscno Žcmaičiuosc".

${ }^{32}$ LVIA F1135/4/25 No.443, pp.457-8 (28.12.42): Michacl's cnvoys ask for help from the grand master and are given the answer that he cannot help due to peace treaty between Poland-Lithuania and the Order. Cf. U. Muller. Das Geleit im Deutschordensland Preussen (Köln-Wcimar-Vicnna, 1991), 266 (27.(19.43).

3.3onas Goštautas' first wife was Dorothca. Their grandson, Albertas, borc arms quartered with the Zadora blazon, which is presumed to represent a female ancestor. The Kesgailas adopted the Zadora arms in 1413 - W. Semkowicz. "O litcwskich rodach bojarskich zbratanych ze szlachtą polską w Horodlc roku 1413”, Lituano-slavica posnaniensia, studia historica, III, p. 88, n. 573 .

${ }^{34} \mathrm{Cf}$. the report of a Lithuanian army's approach on Memel in November 1453: "dic obirsten heren der lande heyssen so wissen wir uff /dic/ neyde nicht anders denn Gastold zcuir Wille, Iwaschke Manivyten zcu Tracken, Sudcway zcu Kawen, Gedekaut zcu Kirssmemcl,Jan Kynssegal zcu Samayten obirster houptman, Stanike Mordasch zcu Willyun und Gedgaut och Kantold och eyn houptman zcu Samayten: Nov. 10 1453: OBA 12,573 (formcrly LXXVIII/a, 95²). Plg. supremus dux / magnus dux. In the 1440)s a starosta and deputy (unterhovetmann) wcrc active in Polotsk: $L U X$ (Riga-Moscow, 1896, repr Aalcn,1981), No. 286, p. 19()-191 [c. 1446-1447]; No. 416, p.287 [Fch. 201448 ]. 
recognition as a specified component part of the Grand Duchy with rights to be ruled by a lieutenant from among its own nobles rather than an appointee from Vilnius. The rights of its nobility were now on a par with those of Smolensk or Brest Litovsk (whose lands also gained a grand-ducal charter around that time). After Kantautas's death the family recedes from prominence in local politics ${ }^{35}$

Kantautas maintained contact with Mykola and in January 1446, during discussions of whether Casimir should be elected king of Poland, he and the Žemaitijans wanted to go to Mykola in Mazovia and to that end he tried to whip up support in Trakai. We might note that the local starosta was Iwaszko Mantigirdaitis, a nephew of Gedegaudas, member of the council of lords and formerly a supporters of Žygimantas ${ }^{36}$. From Długosz we can understand that this was part of a muted general opposition to Casimir-Goštautas which was willing to consider the election of Bolesław of Mazovia as king with Mykola as grand duke. The reason for opposition, according to Długosz was "propter Lithuanorum fluxas et in assistentiam Duci Michaeli praestandam, proclivas mentes, qui duci Kazimiro erant infensi, quod rem publicam eorum non per se, sed per Gasthawdum, cui parere indignum iudicabant, administrabat" ${ }^{37}$.

During 1446-7 and the election of Casimir as king of Poland, both Polish and Lithuanian sides were unhappy with the prospect of having to share a ruler - not so much with the principle of union but with the implicit loss of influence when the ruler was perforce absent from local pressure. The Lithuanians, as we have seen, considered Mykola's candidature again while the Polish crown was offered to Bolesław of Mazovia, a means of maintaining the close alliance of Poland and Lithuania (in the end Bolko was Mykola's heir) whilst ensuring the nobles of each realm a king of their own to dominate. Mykola's case was manipulated by Oleśnicki in Kraków in order to embarrass and undermine the grand duke-king and weaken opposition to his idea of centralised power (which he regarded as his to dominate). Oleśnicki's repeated pestering of the king-grand duke over Mykola's birth right (to the duchy of Trakai) was intended to weaken grand-ducal power in Lithuania in a way similar to that in which royal power in Poland was divided. However, Casimir made his dynastic position abundantly clear $^{38}$. This is a matter on which Casimir remained firm throughout

3S. C. Rowell. "Karas ruscno Žcmaičiuose".

${ }^{36} L U$ X, No. 192, p.127 [cxtract]; full text in: S. C.Rowell. "Karas ruseno Žcmaičiuose", app. No.6.

${ }^{37}$ J. Długosz. Historia, V, cd. I. Żegota Pauli (Kraków,1878), 21. Goštautas referred to in Deodatus Septennius's memorial as 'administrator': "Dcodato Septenijaus Goštautų 'Pancgirika'”, cd. S. Lazutka and E. Gudavičius. Lietuvos Istorijos Metraštis 1976, 82.

${ }^{38}$ behelt beide landt als wol Littauwen als Polan und ist sust kein grosfurste zcu Littauwcn" LU X, 378, p.258 (10.09.47); Olcśnicki and Mykola: J. Długosz. V, 35-6, 87 
his reign ${ }^{39}$. It seems that Casimir's long and extremely coy deliberation over acceptance of the Polish crown was motivated in part by the need to call Oleśnicki's bluff and weaken his position among the Polish nobility by providing space for his Great Polish rivals in the queen's retinue to consolidate their political influence ${ }^{40}$. The Lithuanian nobility also appear to have appreciated the danger of dynastic division of grand-ducal territory.

In 1448 Mykola set about seeking support in the south and east against his cousin. He joined forces with the Tatar khan Sed Achmet. In 1450 Mykola was in Moscow, having gathered an a Tatar force which the Teutonic Order's spies estimated at 40,00041. The following year he joined forces with Ivan Czartorysky, despite the fact that the latter had murdered the prince's father. This alliance and repeated attacks on Volyn' and Kiev, Senko Gedegaudas and Iwaszko were sent to treat with Mykola by Casimir and agreement concluded. At the height of the disturbances Oleśnicki pressurised Casimir to grant Mykola possesion of his inheritance - without success ${ }^{42}$. In these years (1451-2) disputing parties in the Grand Duchy exploited the possibilities offered by divisions in neighbouring realms, especially among the Crimean Tatars to harass contended territories in Lithuanian/Polish Rus.

Early in 1453 (before February 25) Bolko's candidature was advanced by his mother in wake of Mykola's death ${ }^{43}$. In the spring a serious attempt was made on Casimir's life in Lithuania. He was in convalescence for 10 weeks before May 17. According to the report of the Order's spy, he was attacked by a nobleman and was saved because a young courtier made the plot known to Goštautas ${ }^{44}$. There seems to have been an aura of fear throughout Lithuania and Poland that there would be violence in the Grand Duchy, in Silesia and in Kujawy - Oleśnicki was reported to have tried to provoke the Kujawians

${ }^{30} 1461$ - J. Długosz V, 314; 1478 - J. Dhugosz V, 669-7(); 1480) - J. Długosz V, 698

"Scc W. Fałkowski. Elita władzy w Polsce za panowania Kaziemierza Jagiellończyka (1447-1492) (Warsaw,1992) and S.C. Rowcll, "Lošçjų likimas: Didysis Kunigaikštis Kazimicras Jogailaitis 144()-1447 m.” (forthcoming).

${ }^{4} L U$ XI (Riga-Moscow,19()5), No.15, p.15.

${ }^{42} L U$ XI, No. 157, p.122: ouch so haben dic Tatteren Iwan Czerteryszke, der Segemunth dirslagen hatt; and LVIA F1135/25/4 No.467, p.577-8. Polish fcars, July 1451, cspecially for Lwow district: Długosz V, 87-8.

${ }^{43}$ Mykola died in Moscow: J. Długosz V, 104-105.

${ }^{4}$ It is unclear whether this attack was made by Casimir's young Russian courticr, Sukhta of Volozhin whosc attcmpt on Casimir's life is recordcd twicc in J. Długosz V, 129 s.d. 1446, and p.139 s.a. 1453, and by the Bychowicc Chroniclc (PSRL XXXII, 159). Goštautas' grandson refers twice to this occasion when Jonas saved the grand dukc's life: R. Jasas, "Lictuvos kanclerio Alberto Goštauto memorialas karalienci Bonai (1525)", VVU Mokslinès Bibliotekos Metraštis 1972 (Vilnius,1972), 242, 248. Volozhin was grantcd to Iwaszko, Casimir's loyal scrvant - pcrhaps as a result of this murder attempt - DMAMIu, No. 1 p. $3 \$ 10$. 
by telling them that Casimir had surrendered some of their lands to his Lithuanians ${ }^{45}$. In June Goštautas refused to go to the Parczew seim, but travelled as far as Brest. His (in)famous threat to send back Polish coats of arms may perhaps have been connected with summons to seim (two from each blazon). In June there were rumours of war in Silesia and discontent in Kujawy ${ }^{46}$. However, despite Dlugosz's contention that no Lithuanian prelate or baron came to Parczew, representatives from the Grand Duchy did attend the Seim:Jurgis Semenaitis, dux Borisch, Onacz, Andreas Sakaitis, Jonas Nyemeraitis ${ }^{47}$. During the Parczew Seim, the cardinal reminded Casimir of the attempt on his life and the numerous rebellions against him (in Lithuania). Both Goštautas and Oleśnicki tried to manipulate this tension in order to win the king-grand duke over to their policy. In July Casimir was in Grodno $^{48}$. On August 2, the Livonian master reported that Goštautas was trying to enlist Tatar support to place Radvila on the throne. It should be borne in mind, perhaps, that the Gediminid candidates, Švitrigaila and Mykola, had both died by this time, and that Radvila would have been a 'grateful' grand duke reliant on Goštautas for his elevation and his maintainence as ruler. A group of nobles wrote to grand master ostensibly to discuss frontiers, but the Order refused to become involved in Casimir's problems and thus draw attention to its own internal troubles ${ }^{41}$. However, despite deep differences of opinion between the ruling cliques of Poland and Lithuania ${ }^{50}$, there was still a united front against the Teutonic Order. Some families, naturally enough, spread their members over several camps: Mykolojus Jonas Niemyr was consistently at the side of Casimir whilst Niemyr was a client of Švitrigaila. In May the bishop of Warmia warned the grand master,that the king of Poland and the Lithuanians had exchanged 'trostlichen reden in unsere Sachen' and that perhaps if the Lithuanians send envoys to Prussia, notice should be taken when friendship comes knocking at the door ${ }^{51}$. The Order pretended not to hear the knocking.

45OBA 12035; 12036: S. C.Rowcll. "Išdavystè", app. Nos. 5 and 4, pp. 25-8.

${ }^{40}$ Or may even not have happened - the armorial dispute is known only from Bychowicc. On other disputes, sce letter of Junc 21, 1453, OBA 12129: "Men spricht, daz sy sich do werden berothen und myt macht zcihen uff dy Slesycr".

${ }^{47} \mathrm{~J}$. Długosz. V, 136 (nullus: p.135). Sakaitis and Nycmiraitis met Casimir's bride later in the summer as she progressed into Poland - ibid.147. We might also note that these same lords supportcd Casimir's candidature for the Polish thronc in $1447-\mathrm{scc}$ S. C. Rowcll. "Lošçų likimas".

${ }^{48}$ Scim: J. Dlugosz V. 139; OBA 12,201: "Euwir erwirdikcit geruche czu wissen also der foit von Heilsberg was czu Garthin bey unscrin gnedigin herren herren konig".

${ }^{40} L U$ XI, No.296, p.261-2; OBA 12,336 [21.08.1453], published Kolankowski. Dzieje, 275 n. .5

${ }^{5}$ kleyne cynunge ist czwisschen den Polen und den Littauwen (OBA 12126)

${ }^{51} \mathrm{OBA} 12042$ |20.05.1453|, "das ir der gleich weldet widder thun was deucht dy fruntschaffter an de thore werden dy besten als bey etzliche gute frunde ouch roten", published: S. C. Rowcll, "Išdavystè", 28 
In September, the Grand Duchy still resounded with complaints that Poles regarded the Lithuanians as their subjects, while in Parczew on September 10 Sonka and Oleśnecki found it necessary to be suppliant on Polish Crown's behalf. In September Jonas Kęsgaila, obirster hauptmann of Žemaitija, exchanged gifts with the Commander of Memel who reported to the Grand Master that the Žemaitijans were planning to march on Lutsk. However, such cooperation between Goštautas and the Žemaitijans did not bear fruit in joint military action $^{52}$.

In Autumn discontent continued, but the main danger had passed. On December 1 a Prussian embassy to Kaunas, Kęsgaila and king discuss matters, but King allowed no word to Goštautas, who had been declared earlier to be in disgrace - "gros in des koniges ungnade ist". There remained serious divisions between Casimir and his former guardian, not only because of events with the Tatars, but also because of the conflict over Lutsk, which flared up again after Švitrigaila's death (or murder) in 1452. Casimir wished to pardon the Lutsk men who had surrendered the town to Polish forces, but Goštautas refused ${ }^{53}$. It should not be forgotten that in 1442 Goštautas had received land at Polona not far from Lutsk. However, these misunderstandings were resolved relatively swiftly.

In April 1454 Lithuania, Poland and the king-grand duke were reconciled ${ }^{54}$. In mid-May Casimir was writing to the citizens of Novgorod that he was summoning soldiers from Lithuania, Žemaitija and Russia to fight the Order ${ }^{55}$. Indeed, contrary to Polish complaints, the Lithuanians took part in the Thirteen Years' War - breaking communications between Livonia and Prussia and taking minimal part in battles. It is perhaps significant that these participants were from the southern, Rus'ian territories of the Grand Duchy and served Casimir personally at court - their participation was influenced by personal factors rather than Lithuanian central policy ${ }^{56}$.

The years 1456-7 mark Goštautas' final attempt at replacing Casimir with a more malleable master, this time with his son-in-law Semen Olelkaitis, husband of Maria Goštautaite $\dot{e}^{57}$. According to Długosz, Lithuania was rift by internal dissension. Mantvydas' kin (genus) and supporters opposed those who wished to dethrone Casimir ${ }^{58}$.

52OBA 12395 (formcrly LXXVIII/a.952): 19.09.1453

${ }^{53} \mathrm{LUXI}$ X No.321, p. 282.

${ }^{4} J$. Dhugrosz. V, 174.

${ }^{5} \mathrm{LU}$ XI, No. 339, p. 297

${ }^{56} L U$ XI, Nos. 339 p.297, 366 p.312 (1454); LU XI, 517, p.411 (1456); LU XI, No.782, p.624 (1458); Lithuanians held prisoner after the battle of Chojnice (1454): OBA 13, 408 (11.11.54) and L. Kolankowski. Dzieje, 287-88.

${ }^{57}$ Polski Slownik Biograficzny 23:4 (zcszyt 99), 746.

${ }^{58}$ J. Dhugosz. V, 228, s.d. 1456. 
In the council of Vilnius (1457) all blame for such machinations was placed on Goštautas and the grand duke reconciled ${ }^{59}$.

After the death of Jonas Goštautas (1458) and clear majority of Casimir, the political complexion of the Lithuanian nobility appears to have been balanced out. The now established ring was under royal supervision if not under royal control. Displeasure continued to be expressed, but serious revolts were rarer than in the first 18 years of Casimir's reign. In 1461 the Lithuanians wanted Casimir to reside in the Grand Duchy or else they would appoint Semen Olelkaitis (an echo of Jonas Goštautas). However, they a agreed to suspend their demands $^{(1)}$. In 1463, they asked for Podol, Belz, Oleszko and Ratno back (as they had in 1451 during the Tatar crisis) - but no revolt enused $^{(1)}$. Fifteen years later the Lithuanian nobles demanded princes Casimir or Albert as lieutenants for Casimir, but the monarch replied, in essence "over my dead body" 12 and two years later in 1480 he ignored the request to stay in Lithuania or leave a son behind him ${ }^{6.3}$.

In 1481, as a result of Casimir's reorganisation of the administration of Kiev, certain alienated Gediminid and Alšeniškiai princes rose up against grand ducal rule: Mikhail Aleksandrovich of Sluck, Ivan Yurevich Alšėniškis and Fedor Bielsky. The Olelkaičiai were discontent with having been denied the possibility of inheriting control of the duchy after the death of Semen Olelkaitis in 1470. The princes were arrested for having abandoned Novgorod to the Muscovites. According to Kievan sources (i.e. Volynskaia Kratkaia Letopis'), the crime of the three princes was known only to $\operatorname{God}^{64}$. What does remain clear is that the lords, Olechno Sudimantaitis and Martin Goštautas, sat in judgement on the rebels and did not intervene on their behalf. Thirty years earlier the Alšèniškiai and Goštautai had been close allies. Do we need starker evidence for the development of noble opinion with regard to treason? Aleksander Jogailaitis characterised this dispute as having been religious in nature but it may be more instructive to describe it in terms of transformed family connections within the circle of governing nobles - closing entrance to the charmed milieu of the lords of the Council and a realisation on the part of cadet Gediminids, that their day had passed ${ }^{6.5}$.

5"J. Długosz. V, 240, s.a. 1457.

(nilJ. Dhugosz. V, 314.

${ }^{6} J$ J. Dhugosz. V, 366; 1451 attempt ibid. 96.

(22J. Dlugosz. V, 669-70).

6.3. J. Dhugosz. V, 698.

${ }^{14}$ PSRL XXXV, p.122; in general, sec A. Krupska. "W sprawie genezy tzw. spisku książąt litcwskich w 148()-1481 roku. Przyczynck do dzicjów walki o "dominium Russiac", Roczniki Historyczne XLVIII (1982), 121-46.

${ }^{15}$ M. K.Liubavskii. Ocherk, 189-9(); F. Papéc. Polska i Litwa na przelomie wieków średnich I (Kraków,19(1)4), 73-4; O.P. Backus. Motives of west Russian nobles in deserting Lithuania for Moscow 1377-1514 (Lawrence KA,1957), 4. 
* * * *

We may summarise that the Lithuanian complaints against Casimir - i.e., that he lives abroad and favours foreigners - were also held by the Poles who complain that he betrays Polish land and interests to the Lithuanians (robbing the Kujawians of Podole). The nobles of central Lithuania and south-eastern Poland were anxious above all that the ruler should reside within their grasp. Modern historians parrot these same complaints - Poles that Casimir was too occupied with Lithuanian matters, Lithuanians that Casimir was a creature of Po$\operatorname{land}^{6{ }^{61}}$. From his itineraries it is clear that the monarch was scrupulous in his division of time between the two parts of his inheritance, residing predominantly in one area if need arose. Despite serious conflicts, the Polish and Lithuanian sides maintained their union. Rebellion by interested ponai was a common occurrence which was spoken of openly, if not with approval. The 1447 Charter for Lithuania promulgated after Casimir's election to the Polish throne decrees that a man's kin and servants will not be punished for his crimes unless they took part in them - the exception being treason. The sudebnik of Casimir (1468) makes no reference to such criminal activity, whereas treason is condemned strongly in the opening clauses of the 1566 Statute $^{17}$. In his letter of 1525 to Queen Bona, Albertas Goštautas stresses that decisions made by the grand duke and the Council must be obeyed ${ }^{6 *}$. In the future, the new families would take care to distance their ancestors from the taint of having conspired against the grand duke. Miechowita records the survival of a song about the "audaces principes Russiae" who murdered Žygimantas, but here the meaning is more "brazen" than "brave"(i).

If actions may be used to ascertain thought, then in the midfifteenth century there was still a marked tendency to regard rebellion as a matter of everyday life. Such rebellions usually mark local grievances - in Žemaitija, Smolensk, Lutsk, Polotsk, Kiev - and searches for clan precedence, especially under Casimir's minority and these tend to diminish in frequency (but not disappear) after 1457-8, the last strike of Goštautas, perhaps because the major dynastic rivals (Mykola Žygimantaitis, Svitrigaila) were gone, perhaps because the central fig-

"The most recent example is W. Falkowski Elita wtadzy, 50.

${ }^{67}(12$ 2.05.1447: CESXV III, cd. A. Lewicki (Krakow, 1894). Nr.7, p.10, §4, "criminibus lesc maicstatis solum cxceptis". For the Sudehnik, scc Kazimiero Teisynas (1468 m.). Sudebnik Kazimira (1468 g.), cd. J. Jurginis (Vilnius, 1967). Sccond Statute, Article 3: Collectanea ex Archivo Collegii Iuridicii, VII (Kraków,1900), 2: "consilium inicrit conspirationcmve conflaverit aut cactum cocgerit adversus salutem nostram".

${ }^{68} \mathrm{R}$. Jasas. "Lictuvos kanclerio", 239.

${ }^{69}$ Macicj z Micchowa. Chronica Polonorum (Kraków,1521), 309: "dc hoc carmen lugubre usque in actatem mcam Lithuani concinnaverunt: Audaces principcs Russiac occiderunt Sigismundum duccm Lithuaniac". 
ure, Casimir, was already strong enough to govern events. To view the conflicts primarily as anti-Polish movements may be unhelpful for this draws attention away from their internal significance and makes Lithuano-Polish cooperation which is also reflected in the sources, too much of a surprise. The $1481 \mathrm{Kiev}$ uprising marks a slightly different type of revolt - against the king, against the diminishing of princely (i.e. alternative Algirdaičian/ old-princely) power and, indirectly, against the power of the Council. It was a fight in which the 'new' nobility played little or no part, except - like Martynas Goštautas and Alechna Sudimantaitis - to sit as judges in the king's court.

It is difficult to assess the impact of fifteenth-century rebellions on the formation of Lithuanian political society. It would be useful (but, given our source base, perhaps impossible) to know more of the relationship between the grand-ducal court and the council, whose membership does not seem to be identical, and competition between Vilnius and its region and the other lands of the Grand Duchy. ${ }^{70}$ Jonas Goštautas has left no record of his views and we may assess them only in retrospect, from the origins-myth of the Lithuanian political elite as recorded in the Lithuanian chronicle. ${ }^{71}$ Sixteenth-century texts may shed some light on how understanding of rebellion as an historical, political reality developed in the Grand Duchy.

In the fifteenth century noble factions rebelled frequently and appear to have been punished little for such behaviour, if at all except where direct attempts were made on the life of Casimir. The murderers of Žygimantas were disgraced, but not executed. This would seem to mark the weakness of the monarch but also, perhaps, either the lack of interest of a consolidated boiar block, or exactly the opposite, viz. a consensus of opinion that Žygimantas was unfit to rule (see below).

In 1525 Albertas Goštautas recalled the Sluck treason, the events of 1481 and the execution, and the Czartorysky murder of Zygimantas in 1440. He took great pains to note that none of his ancestors were ever executed (unlike those of his competitors) and that his grandfather Jonas defended the minor Casimir against all his competitors and even against the will of his fellow nobles.

In the Bychowiec Chronicle we read much, for example, which seems to bring doubt on the course of events as we have charted them. The Žemaičiai favour Mykola, eject Kęsgaila and elect a local boiar, Daumantas, brother of Kantautas. They march on Kaunas and battle looks likely. Goštautas tells the grand duke it is not proper to fight his own people and so Kantautas is despatched to make peace which he

${ }^{71}$ W. Falkowski. Elita wtadzy has done much for the Polish clitc; cf. W. Jarmolik. "Karicry politycznc dworzan litcwskich Kazimicrza Jagicllończyka”, Europa orientalis, 93-101.

${ }^{71 P S R L} \times X X \mathrm{X}, 128 ;$ S.C. Rowell. "The Baltic and the new Lithuanian political ćlitc, ca.1435-1475" (forthcoming). 
does. Battle has been avoided, Kantautas becomes seniunas for three years and is then removed by Kęsgaila. This is a deliberate (mis)understanding of the mid-fifteenth century which is rewritten in sixteenth-century terms. The Žemaitijan rebellion is painted for the justification of the loyal sixteenth-century state officers such as the Kęsgailas and this involves the diminution of the extent of Žemaitijan disobedience. Kęsgaila is depicted as starosta (no hint of his having been dismissed by Zygimantas) but innocent of any involvement in the uprising, and Kantautas, the rebelling starosta, is redeemed as Goštautas/Casimir's peacemaker (in place of Mantigaila). Thus there was no battle with Casimir; Kantautas, the successful rebel becomes the peace maker and his otherwise unknown brother the dangerous insurgent. There is no mention of his being out of favour or conniving with Mykola Žygimantaitis. The disputes of the 1450s appear only as the discontent of a Russian princeling against whom Goštautas defends his master: no widespread violence in 1451-3, no Radvilas-Tatar plot. The Olelkaitis rebellion of 1481 is not mentioned at all. What we know of it comes from a very short reference in Russian chronography and a summary of the trial reports made in the mid-seventeenth century ${ }^{72}$.

The attempt on Casimir's life (used twice by Długosz!) is portrayed as the salvation of the king by Goštautas ${ }^{73}$. Sukhta of Volozhin's attempt to murder Casimir during a hunt is portrayed as an example of how Goštautas jnr saved the grand duke by reporting Sukhta's plan to Jonas. Thus, the treacherous Sukhta was executed and Goštautas saved the day.

In conclusion we may say:

1. that the formation of a political nation and the consolidation of its leading group took place over a long period of time. This consolidation was aided considerably by the years of Casimir's minority and the disputes which dominated those times - Długosz notes seven particularly dangerous revolts.

2. that the fifteenth-century rebellions were largely a response to local dissatisafction with central interference or neglect, and that local sensibilities had to be respected, especially at the beginning of the reign as is evident from the Žemaitijan reaction to Goštautas' regime and the maintenance of Kantautas in tandem with Kęsgaila. They seem to be anti-Polish only in an indirect sense.

3. this tendency to particularism was no less pronounced in

\footnotetext{
${ }^{72}$ Excerpt from "Fragmentum de supplicio ducum Slucensium Vilnac sumpto Anno 1487" in Kolankowski.Dzieje, 350, n.3; MS: MAB F17-27, ff. 161v-162: Volumen sccundum, zwicrający sobic Dzicje od Zygmunta I do Władysława IV... published in full:

S. C.Rowcll. "Išlavystè", app. 7, p. 29-30.

${ }^{73}$ Lietuvos Istorijos Metraštis (1976), 82; Acta Tomiciana, cd. S. Górski. VII (Poznań, 1859), 260), 265, 267, 268-9; R. Jasas. "Lictuvos kanclcrio", 242, 248.
} 
Poland than it was in fifteenth century Lithuania. On occasion, rebellion in Poland (as in Silesia in 1453) ran in parallel with troubles in the Grand Duchy. However, rebels in various parts of the Jagiellonian monarchy, although aware of events in other districts, do not appear to have made efforts to join forces with other discontented groupings.

4. Casimir successfully avoided increasing kinship involvement/ competition in government. The crises of early fifteenth-century Lithuania were prompted not so much by a dearth of Gediminids as by a surfeit of such siblings. Having successfully outlived both Švitrigaila and Mykola, Casimir had no intention of allowing his distant kinsmen to return to political power. The declaration made in 1447 that Casimir would appoint no grand duke during his life time was maintained throughout the reign. However, while excluding his kin he (unwittingly) opened the door to the boiars/magnates.

5 . that the inner circle of noble politicians was not only constant vertically, with sons following in the service footsteps of their fathers (Goštautas, Kęsgaila etc) but also horizontally - with the intermarriage of Casimirian apparatchiks ${ }^{74}$. Thus, if we look at a list of charter witnesses we find: 1452: Bishop of Vilnius, Yury Semenovich Alšèniškis, Jonas Goštautas, Jonas Mantvidas, Sudivojus, Onacz; in 1453: Goštautas, Jonas Mantvidas, Sudivojus, Gedegaudas (Senka), Kęsgaila, Kantautas. Sudivojus was Kęsgaila's brother, the Mantvydai were related to the Gedegaudai (and via Anna Vytautiene to Alšèniškiai); the Goštautai were affined with the Alšèniškiai. By the end of the century entry into this charmed circle of affines and friends was as difficult as marriage with the Gediminids. Their interests were formed not only by family connections but also after 1492 by legal privilege.

6. importance of family tradition in the consolidation of the political nation, of inherited interest, of a corporate 'alternative' to the royal line. In the early 16th century the Goštautai took pains to make clear what should be regarded as treason - usually action against the monarch which did not involve (inter-related) members of his circle. The fifteenth-century political mousse had formed a hard, almost inpenetrable outer skin. It is notable that earlier alliances of interest did not survive in later alliances of family: Yury Ostrogsky was Jonas Goštautas' ally in 1451, but his indirect descendant Konstantin was Albertas Goštautas' opponent; the Alšeniškis alliance with Jonas Goštautas in the 1450s in favour of the Olelkaitis candidacy did not prevent Martynas Goštautas from sitting in judgment on the Sluck conspirators of 1481 . It may be no coincidence that the Roman Ori-

${ }^{74}$ Also effective in carly years of Žygimantas - sce Vilnius chartcr, Scpt. 231432 (MABR F1-14): “Alcksandr Vladimirovich, Scmen Ivanovich, a panove Pan Ostik ... Pan Kezkgailo, ... Sunkgaila ... Romvolt' ... Pctrash, ... Kgastovt” ... Rodivil Ostikovich”. 
gins myth which scholars cite in the context of ethnic identity is also a dynastic myth uniting the leading families in the aristocratic right to participate in government. It illustrates how a group of social equals, led by a prince of undeniable quality came to a territory whose borders are carefully described in the light of competition with Prussia. In its framework which we have paraphrased here, this legend it reflects the complaint of the Prussian townsmen and nobility against the Teutonic Order (1440-53), the Orsachen des Bundes, that all came together from overseas to take part in the conversion of pagans and the creation of a political community ${ }^{75}$. Hence everyone had a right to share in power. This is the role shared by the Goštautai and various grand dukes, as described in particular by the Bychowiec Chronicle and by the Goštautai, Mantvydaičiai, Davainai, Radvilos, Alšèniškiai and Giedraičiai with the Jagiellonians, as portrayed in the Lithuanian chronicles. The Goštautas role in Lithuanian history is made to shadow that of the Gediminids: Vytenis is portrayed as a marshall (the office held by Jonas Goštautas) from the Columns coat of arms (ditto, Goštautas). The main achievements of Gediminas are given as the struggle against the Teutonic Order and the conquest of south western Rus'. The Goštautai assist both policies. Petras Goštautas marries a Polish woman and brings Roman Christianity to Lithuania for the first time, prefiguring Jogaila's role in Lithuano-Polish history.

7. During rebellions lords changed sides according to family or local interests and not in the name of a general political community called Lithuania. Collaboration with Tatars and Muscovites was not taboo. Noting the shortage of suitable Gediminid candidates for grandducal honour, Goštautas was willing to consider elevating a Radvila to that rank.

8. Only in early the sixteenth century did most Lithuanian nobles come to regard themselves as tutores ducatus, and the interests of the state as their interests which must be protected jealously. By the mid-15th century Polish nobles had already been claiming this royal prerogative for themselves.

Appendix: The Image of the bad grand duke: Žygimantas Kęstutaitis

The murder of Grand Duke Žygimantas in Trakai presents a minor enigma for historians. The accusations of political tyranny, pa-

75" Item vort woren land und stetc betrachtende, wic ire altveter // und vorfare in dic lande Prewssen weren gekomen wedir dic heiden getrewlich fechtende mit blutvorgiszunge, die sie zum christenglouben haben hulfen brengen, die lande haben hulfen bekreftigen bisz an dic ende, als sic hewte stecn ouch ander grose mechtige herren und lande, dic in iren landen gegrenitzt haben, gehulfen zum christengelouben zu brengen, und das gote zu loube und umb irer freiheit willen gethoen haben ..." 10.08.1453, Graudenz: Akten der Ständetage Preuf.rens unter der Herrschaft des Deutschen Ordens, cd. M. Töppen. IV (Lcipzig, 1884; Aalcn, 1974). No. 17, \$64, pp.29-30. 
gan bestiality and communion with witches that we find in Długosz's account of this regicide were translated at the end of the fifteenth century into a bear story which spread through western Europe thanks to Piccolomini's neo-classical history of Europe and its vernacular variations. In the sixteenth century Polish and Lithuanian accounts began to include attempts to defend the grand-ducal entourage as a whole from accusations of treason by making mention of an unsuccessful attempt to save Žygimantas's life on the part of a chamber servant named Slavka $^{76}$. In 1928 Kazimierz Chodynicki published his analysis of the development of the story of Žygimantas's murder and the subject requires little further study here. Our present aim is to review events preceding the murder and note whether Žygimantas was really so tyrannical and how a bear replaced witches as 'evidence' of Žygimantas's cruelty.

Długosz notes that rumours spread in Lithuania of Žygimantas's plan to execute leading nobles after the octave of Easter 1440. In order to preempt this tyrannical act, a group of Rus'ian and Lithuanian nobleman led by Czartorysky secreted themselves in the grand duke's chamber while the latter and his servants were hearing Mass. The conspirators rushed on the grand duke, dealing him many deadly blows and sent his corpse out of the castle in a driver-less cart before taking control of the castle and treasury. Žygimantas was buried "with due honour" beside Vytautas in Vilnius Cathedral. Despite the unavoidable fact (i.e. treasonable murder), Długosz stresses the limited participation in the murder, the anonymity of the aftermath of the crime and the good treatment of the corpse. He expresses his horror at the felonious behaviour of men whom Žygimantas had promoted, but comments in extenuation that the grand duke had been "profundae ... vir tum saevitiae tum avaritiae, pronus ad cuiuscunque et quaecunque de causa supplicium, spolium atque necem, statura mediocris, sermone rarus, sectator luxuriae, ira praeceps et turbidus, habendi cupidus" These characteristics fit Długosz's image of the tyrannical ruler, such as Švitrigaila, Sigismund of Luxemburg or Bolesław Rogatka ${ }^{78}$.

The tyranny of Žygimantas Kęstutaitis as described by Długosz is a very carefully focussed account of reality, as we must expect from this historian. Žygimantas was no more brutal in his methods than other grand dukes. The bojars whom he executed in 1434

75PSRL XXXII, 156. A document of 1436-7 was witnessed by Žygimantas's supremus cubicularius, named Claubo: Leontovich, Akty 1.1, No. 6, p.6

${ }^{77} \mathrm{~J}$. Długosz. IV, 620).

${ }^{78}$ M. Koczcrska. "Mentalność Jana Długosza w swictle jego tworczości", Studia Źródtoznaweze 15 (1971), 117-23; for Bolcsław the Bald - ipse per incantaciones et carmina fascinatus ct illaqucatus fertur amore, ut alioquin vir natura scverus ct ferox, libidinc illius domitus...", J. Dlugosz. Annales seu cronicae incliti regni Poloniae VII-VIII, cd. D. Turkowska (Warsaw,1975), 190) s.a. 1276. 
(Rumbaudas, Jaunius and Šediboras) had plotted with the Teutonic Order and Švitrigaila against him in favour of the "son of the Polish king". Their elder brother, Kęsgaila, survived in Žemaitija and, although no longer starosta, he retained a role as diplomat ${ }^{79}$. Žygimantas's drowning and poisoning of his opponents (also not the most loyal of Lithuanian nobles) after the Battle of Swieta/ Pabaiskas (1435) was hardly, perhaps, consonant with the spirit of Christian forgiveness, but it is hardly any more 'tyrannical' than the action of other rulers. The same may be said of his beheading of the leaders of the revolts in Polotsk and Vitebsk in 1437. Their fate was sealed by their wavering loyalty ${ }^{\mathrm{g} 0}$. All grand dukes found it necessary to maintain control of these commercial outposts if they were to survive in power. In short, it was not so much the quality of Žygimantas's wrath as its quantity. There is no need to posit mental illness on his part (the grand duke requested a physician from Livonia in July 1439 -but psychosis is not the diagnosis! $\left.{ }^{81}\right)$.

After his military victory at Pabaiskas, Žygimantas failed to win the peace and maintain the support of the mainstays of grandducal finance and the confidence of his boiarocracy. His attempts to form alliances with the emperor, with the Livonian branch of the Teutonic Order came to nought ${ }^{\$ 2}$. Žygimantas's imperial ally, Albrecht II, had died the previous October and there was no prospect of bringing in the Empire to balance Polish influence. The Livonian alliance had come to impasse, and it seems unlikely that a ruler who lacked the support of Livonia's eastern trading partners, Polotsk, Smolensk and Vitebsk would regain the Order's support. We ought perhaps also to note that the most obvious (if not the only) change in administrative officers from Žygimantas's to Casimir's "government" was the appointment of the former grand-ducal lieutenant of Smolensk to the vaivadyste

${ }^{70}$ OBA 6886 (formerly XVI.13) Nov. (04 |1432|: herczog Segemonth hette gefangen herren Rombolt, Schedebar hoptman von Kaywen, Jauwned, dy drye bruder und gebe in scholt, wy das sy in woldin vorraten, sam sy vorraten hetten herczog Swydergal und welden dy lande zeu eygen des koniges son von Polen. Das ander das sy noch dem thode herezoge Wytholdis hetten abchandig brocht den schactez Wytholdis, zo das her eren eroperen noch dem lande wor komen zcu fromen"; Kçsgaila as cnvoy in prisoncr-of-war negotiations: OBA 7326 (formerly XIII.(L.S.).26), June 151437.

${ }^{80}$ Pabaiskas: J. Dlugosz. IV, 565; CESXVI, No.89, p.99; J. Grygicl. Życie i dziatalność Zygmunta Koryhutowicz. Studium z dziejów stosunków polsko-czeskich w pienwszej potowie XV wieku (Wrocław-Warsaw-ctc,1988), 11()-112; for Polotsk and Vitebsk (and Smolensk too), scc $L U$ VIII No. 462, 998; IX, Nos. 2, 1(12, 133; murder of cnvoys - LU IX, No.133, p.89.

${ }^{81} L U$ IX, No. 477, p.342 - meyster Johan; for mental illness as an explanation, sec B. Barvin'skii. Zhigimont Keistutivich velikii kniaz'litovsko-ruskii (1432-1440), Istorichna monografia (Zhovka,19()5), 118.

"A. Lcwicki. "Zygmunt w. ks. litewskicgo z królcm rzymskim Albrechtem II", RAU, wyd. hist.-filoz. Scrics 2, XII (1899), 292-319; R. Varakauskas. Lietuvos ir Livonijos santykiai XIII-XVI a. (Vilnius, 1982), 106-10. 
of Trakai in 1440. The alienation of these northern trading centres was perhaps literally fatal to Žygimantas. There is no evidence that he was planning to change his administration drastically, but there are grounds to believe that his own creatures numbered themselves among his enemies. It seems, quite simply, that the grand duke's luck ran out, if maintenance of a delicate political balance is a matter of fortune. $\mathrm{He}$ could not control his land - in 1438 he was unable to provide Metropolitan Isidore with safe conduct through Ž emaitija ${ }^{8.3}$; he could not rely on southern or north-eastern areas of the Grand Duchy. He was treading water. The amateur psychologist may exhibit less impertinance if he attribute Žygimantas's failure not to madness or badness but to "younger sibling" syndrome - Žygimantas was Vytautas's brother, but that was not enough to guard him from the political consequences of his actions.

Žygimantas had Polish mercenaries in Trakai whose maintenance was very costly and whose wages were not paid in full. He is also known to have been importing arms from Gdańsk for which he failed to pay. ${ }^{84}$ He needed to buy friends. The leading noblemen of the Grand Duchy had witnessed Žygimantas's last confirmations of the union with Poland (in 1434, 1437, 1438, 1439, 1440) and remained loyal to Jogaila's sons. As for King Władysław, he was en route to Hungary, providing a convenient central vacuum in which the nobility could act without involving him. It is also worth noting that Švitrigaila, who was safely in Moldavia (a staging post on the Polish route to Hungary...), was in no position to resurrect military support for his political pretensions. He too was swift in June 1440 to recognise Władysław’s decision concerning the Lithuanian succession.

The conclusion drawn by Dundulis (inter alios) to the effect that Lithuanian noblemen objected to the grand duke's showing favour to lesser nobles or lower orders and to an alliance with Poland is not supported by the evidence and rises from a perceived need to trace the fortunes of pro- and anti-Polish policies. There is no evidence that a "special Polish delegation" was active in the Grand Duchy in the late 1430s or that the events of March 1440 were Polish-inspired. If by 'Polish', Oleśnicki is meant, his ambitions would have been strengthened by continued discontent in Lithuania. The maintenance of Polish mercenaries by the grand duke is an important aspect of the state of Lithuanian politics: local forces were not enough for Žygimantas to maintain order in a divided Grand Duchy. It is unfortunate that the

\section{$83 L U$ IX No.267, p.159}

84 On September 271447 the Grand Master interceded on behalf of Gdansk with Casimir "wic her den etwan irluchten fursten und herren Sigmunde grosfursten zeu Littauwen uff dic zecit etliche armbreste und salinter || und swebel verkoufft hette, dic $\mathrm{cm}$ nach nicht beczalet weren em zcu grosscen schaden”, OBA Ordensfolianten 16, p.1209 10 . 
reference to these soldiers is so taciturn. Indeed "Polish" is just not good enough as a descriptive term. It would be more useful to know where these "Poles" came from. From Mazovia, perhaps, where Kęstutid dynastic ties were strongest, or from Great Poland, where the base of Jakób z Kobylan who fought with Vytautas at Novgorod in 1428 and Žygimantas at Pabaiskas seven years later, was, or Silesia? It is highly unlikely that Little Poland under the thumb of Oleśnicki was serviceable.

Disputes over how to respond to Polish policy were a constant feature of Lithuanian political life throughout the centuries of the Union. However, this problem does not appear to have been the reason for Žygimantas's death. Lithuano-Polish relations were chaotic throughout the 1430s. Žygimantas himself could sway from public alliance through private conspiracy to public objection in the span of less than a year. In June 1437 the grand duke had fallen into serious dispute with "Poland", in December he renewed his pledges to Władysław and the following June he was in secret alliance with Emperor Albrecht II ${ }^{\mathrm{x} 5}$. Anti-"Polish" perhaps, but also reliant on Polish mercenaries costing in excess of 100,000 kop groszy. Žygimantas's proud 1439 claim to the emperor that "post decessum nostri germani dive memorie domini Witoldi, iure hereditario teneamus et possideamus, veroque et iusto tytulo ad nos tamquam ad verum heredem sit devolutus" $"$ is a good piece of rhetoric, but it is not strictly true.

The murder of Žygimantas is best seen as one of the first examples of collective noble policy in the Grand Duchy of Lithuania, embracing dissatisfied factions throughout the realm, including the supporters of Švitrigaila, who was also unfit as a candidate for the whole of the Grand Duchy, as the result of Pabaiskas underlined. In 1432 the nobility was divided in its choice of grand duke, 1435 dealt a strong blow against Švitrigaila and by 1440 it was clear that the Kčstutid option was also unsatisfactory. The same nobles appear throughout the 1430s in documents pledging allegiance to Jogaila and his sons and promising, along with Žygimantas, to hold their offices, like Daugirdas $^{87}$, lieutenant of Vilnius, for Władysław Jogailaitis in the event of Žygimantas's death. As events turned out, they did exactly that. This does not mean that Lithuanian nobles agreed with their Polish

\$5" und alz wicr ouch von dem boten sien berichtet, so) solle der cigenen herre herczogh Segemundt wollen wesen. Alzmorne in cuer vorsameluge mit ganczer macht unde wil dem hern herczogh Swidrigaln enkegen czihn. Wente der mit dryn hecren gancz starkelich. Also das men sich wol vormittet, das sic in desser nehstvol wochin streten werden. Wente wier ouch von dem vorbennon boten berichtet sien, das der herre herezogh Segemudt unde dic Polen sundir cnde von dem tage geschdciden sicn" - Junc 15 1437, OBA 7326; Akta unji Polski z Litwq 1385-1791, cd. S. Kutrzcba and W. Scmkowicz (Kraków,1932). No.63, p.1068; A. Lcwicki. "Przymicrzc”, 309.

${ }^{86}$ CESXV II, No. 261, p.403.

${ }^{87}$ Akta unji, No. 62, p.105-106, of July 11437. 
counterparts that the Grand Duchy was subject to the Polish Crown, but it does mean that serious objection to the very principle of union with Jagiellonian Poland was not voiced widely. A reasonably consolidated group of noblemen removed a widely unsatisfactory ruler, avoided replacing him with another strongly biased representative of the older generation who likewise could not maintain wide support (Švitrigaila) and settled for the solution to which they had repeatedly given their consent over the past decade - the will of King Władysław. In taking on the king-supreme duke's brother, Casimir, as grand duke, the nobility gained a young ruler whom it might mould in its own image (in theory!). As Długosz tells us, the Lithuanian barons set about teaching Casimir their language and customs. The death of Žygimantas was essentially an internal affair and it is unnecessary to posit unsubstantiated theories that "the threads of the rebellion against Žygimantas would lead to the palace of the Polish king"ss

Why was Žygimantas vilified after his death? The answer seems straightforward enough. He was murdered and his killers had to be excused. The cause of the Kestutids died with him, except for isolated pockets of resistance which fostered support for his son - especially in Žemaitija. The majority of the bajorate appears to have accepted that decisions over the grand ducal throne were to return to the central Jagiellonian line - resident in Kraków and Budapest, rather than to the other Algirdaičiai (Švitrigaila) or Kęstutaičiai (Mykola and Bolesław of Mazovia). Poor Žygimantas was tidied away into his tomb. The origins-myth of the Lithuanian political establishment which stresses the flight of the ancestors of the Jagiellonians and the Lithuanian nobility from the hands of a cruel tyrant (Nero) and justifies the right of the nobility to share in government with the grand duke reflects the murder of the "tyrant" Zygimantas.

The Długossian description of Zygimantas fits in with his other tyrannical stereotypes - from Polish history: from his cruelty and greed and propensity to punish, rob and kill on any occasion to his medium stature, taciturnity and yearning for luxury. His communion with witches, the sacrifice of noble blood to wild animals and referral to omens make him a monster any healthy bojar might kill.

Długosz accuses the grand duke of being subject to fortunetellers and witches (pythonisse) whose prophecies meant death to Žygimantas's perceived enemies. It was reported that a week after Easter leading members of the Lithuanian aristocracy were to be put to death and their property sequestrated. Human blood mixed with that of beasts was to be offered up to idols in order to tell the future and traitors be revealed by the denunciation of evil spirits. Some researchers see this as a source of Lithuanian pagan practice, which it

${ }^{8 x}$ B. Dundulis. Lietuvos kova, 172, n.53. 
might just be, however, it seems more than likely that these pythonisse and their human sacrifices are examples of tyrannical behaviour which is linked by writers in other kingdoms with witcheraft. As Michael Jones has noted of France, "the use of spies and informers, coded and cryptic messages, poisoning, assassination, torture, bribery and blackmail ... and also the invocation of intangible occult forces, sorcery, divination and black magic, to attain political ends, all these are integral to the most notorious cases of treachery" " was attributed not to the traitors, but to the 'tyrant'. It may be significant that the abominations attributed to Žygimantas by Długosz are not mentioned elsewhere by him as typical of Lithuanian behaviour. This lurid passage in the chronicle is not evidence of Lithuanian pagan religion. The witches are described in standard classical vocabulary rather than the more ethnographic turns of phrase which the chronicler employs in his general accounts of native pagan practices.

In the later fifteenth century Aeneas Silvius Piccolomini reported or invented a story from Jerome of Prague concerning the tyranny of Vytautas, accusing him of sewing traitors into bear pelts before feeding them to his own bears - and Švitrigaila, who is credited with keeping a wild bear as a pet and was killed by a young nobleman to imitated the bear's pawing at the duke's door in order to gain admittance to murder the ruler. The confusion of Švitrigaila with Žygimantas is not difficult to understand. Both dukes were active in debates in fifteenth-century church councils where each was accused by the other and Polish and Teutonic representatives of sculduggery ${ }^{90}$.

The bear takes the place of the pythonisse who do not feature in accounts other than that of Długosz. Its presence acts as a device to removes blame for complicity in the murder from the grand duke's own household. Długosz mentions that the latter was in the parish church at prayer, Piccolomini speaks of trickery, whilst sixteenth and seventeenth century chronicles provide a Kievan servant who reluctantly does not report the plot because he understands that

${ }^{80}$ J. Dlugosz. V, 620-21. Cf. Jones. "Bons Bretons", 92 and M. Valc. Charles VII (London, 1974), 29. "It was becoming part of the ritual of political assassination to scver a hand- a hand which, the writers of propaganda literature claimed had been guided by sorcery and the invocation of demons. Witcheraft was added, almost de rigucur, to the alleged crimes of thesc victims of factional politics".

9)“ detrectantes impcrium insutos ursina pelle viventibus ursis, (quos cam ob causam nutricbat) dilaniandos obicctavit" (of Vytautas; of 'Švitrigaila': ursam nutrivit, quac sucta cx manibus cius pancm accipcre sacpe in sylvas vagabatur ... conspiravere nobilcs aliquot adolescentes adversus principem atque ursac modum secuti sumptis armis cubiculi principalis ianuam confricaverc. Credit Suidrigal ursam adessc ostiumque apcruit ibique mox ab insidiantibus confossus intcriit", citcd from Acncas Piccolomini, De Europa chapter 26, citcd in A. Janulaitis. Enejas Silvius Piccolomini bei Jeronimas Pragiškis ir ju žinios apie Lietuvq XIVIXV amž. Istorijos-kritikos piešinys (Kaunas, 1928), 58. For the ccho of Tacitan style in the description of Vytautas, cf. Annales XV,44. 
Žygimantas is cruel, and a loyal body servant, Slavka (also of Slavonic origin), who may or may not be connected with Žygimantas's chief cubicularius recorded in the Lithuanian Metrica, made a futile attempt to save his master but was thrown out of the castle window for his pains. This pale example of noble defence of the ruler takes shape in Bychowiec, Stryjkowski and later, the Jesuit historian Kojałowicz (1669). The bearskins appear to be a fantasy based on the cruelty of Nero, who sewed Christians into animal skins and the exotic bear culture of eastern Europe - Grand Duke Casimir, for example, is known to have employed Russian bear tamers. This story spread further into German printed chronicles where it becomes the main piece of topical information about Lithuania, expanding the old accounts of woods and fens ${ }^{\prime \prime}$.

The general image of the Lithuanian as a shocking barbarian - hairy, bestial, stinking rich, but irredeemably uncultured took root in the fifteenth century and surely influenced the accounts of Žygimantas/Švitrigaila. We find it in accounts of Vytautas presented to the Council of Basle which preface each extravagant titbit of information with the words "who would believe it?". When Ghillebert de Lannoy came to visit Vytautas at Trakai in 1413 he noted that the grand duke maintained a reserve with various wild beast including bears. Other correspondents mention the excellent hunting available in the region and, in the case of Albert Hohenzollern, first duke of Prussia, pass on gifts of bear-gnarled hunting equipment ${ }^{32}$. Bear tamers, usually of Rus'ian origin, provided popular entertainment for various courts

"Die Schedelsche Weltchronik. Nachdruck der deutschen Ausgabe von 1493, cd. R. Pörtner (Dortmund, 1993), cclxxviiir.

92" Item cn la dite ville de Trancquenne y a ung parcy enclos ouquel sont de toutes manieres de bestes sauvaiges et venoisons dont on peut finer es forests et marches de par dcla. Et sont lcs aucuncs comme bocufz sauvaiges nommez ouroflz, ct autres cn y a commc grans chevaulz nommez weselz, et autres nommez hellent. Et y a chevaulz sauvaiges, ours, porcz, cerfz, ct toutes manicres de sauvaigines", P. Klimas. "Ghillebert de Lannoy. Dvi jo kclionćs Lictuvon Vytauto Didžiojo laikais", Praeitis II (1933), 153; the "quis crederct?" style of Council dispute is best excmplificd by Nicholas Lasocki's 1434 sermon called by the Teutonic Order "magna mendacia", published from the Schloss Zcil ms. in S.C. Rowell. "Dvicjų Europos kraštụ ryšiai -LDK ir ispanụ karalystćs 1411-1412 m. ir 1434 m, tckstụ švicsojc", Acta Historica Universitatis Klaipedensis (forthcoming). On Octobcr 91446 the Grand Master waxed eloquently to the dukes of Milan (OBA OF $16 \mathrm{pp} .244-245$ ) concerning the fauna of the Baltic region - "quarum alique de regno Polonic, de magno ducatu Litwanic Russicque ct de terris Livonic ordini nostro subicctis cxtant nobis misse ct arte annetarum ad ipsas diversar reptilia ct ferarum rapaciteque multum abiles et aptas effeu prout graciosissime vestre magnificencic aucupatos $\mathrm{cedem}$ vre screnitati excmplose dcclamabunt". Cf. Albert's gift to Radvila 21.11.1555, PKKA, Ostpreussische Folianten 54 p.976-7- spcar for bear hunting: quibus instrumentis ipsimet hactenus in venandis et perscquendis urses, uris ct bisontibus non infeliciter sacpe usi sumus mittimus, maius venabulum ad ursum urumuc in retibus scu coram || canibus figendum ct capicndum accommodatum cst .... in supcriorc partc hastilis infra cuspidem ct ferramentum ursinorum dentium vestigia cernuntur". 
in the region. In Gdańsk at the beginning of the fifteenth century we find the Commander paying for this type of amusement and in the 1470s Casimir's chamberlains in Sandomierz enlisted the service of Rus'ian animal trainers ${ }^{13}$. In the sixteenth century Lithuanian writers joined the marvel school of nature literature, fitting their homeland into cliches of classical philology: the Lithuanian aurochs, the great river Nemunas. Ambassadors to Lithuania were dumbfounded by the extravagance of their reception - gifts, entertainment and ceremonial ${ }^{14}$. In the nineteenth century Prosper Merimée used a Lithuanian motif in his novela "The bear" which tells of the ursine preoccupations of the the Šemieta, influenced by information of the Smorgońska Bear Academy.5.

\section{ŽYGIMANTIANA}

1

\section{2, December 12, Memel}

The Commander of Memel informs the Grand Master of divisions among the Lithuanian nobility over who should be grand duke. Žemaitija is quiet.

A: Berlin, PKKA, OBA 6277; paper, 30 × $21 \mathrm{~cm}$, no water mark; tracesd of red seal. Dorso: address and postal notices

Meynen garwilligen, underthenigen scholdigen gehorsam nu und zcu allengecziten zcuvor. Erwirdiger, lieber, genediger her homeister, zo euwer genode mir schreibit under vil sachen. Sunderlichen euwern genoden zcu schreibin von den Samaythen, zo

${ }^{13}$ Marienhurger Tresslerbuch der.Jahre 1399-1409 cd. Joachim (Königsbcrg, 1896, rcpr. Brcmerhaven, 1973), $1(17$ (Fch. 1401) itcm 8 scot cymc Rusin, der mit cymc bern ummc zoch, p.534, Feb 14()9: item 1 fird. cyme armen manne, der dem meyster 2 junge becrn brochtc; Jurgizcth, the chamberlain to Casimir's sons reportcd paying a Russian bear tamer: 3.(1)8.1478: Ruthenis cum urso florenum ad relacionem Jurgyzcth; acta sunt hec SandomiricRachunki królewskie z lat 1471-1472 i 1476-1478 cd. S. Gawęda, Z. Perzanowski and A. Strzelccka (Wroclaw-Kraków,196()). 250 and ibid. 247 we find under 25.07.78 ruthenis cum urso dedi marcam ad relacionem Sbersky - Shersky was Casimir's chamberlain.

${ }^{24}$ Sec Jerome Horscy's account of what amounted to temporary kidnapping at the hands of Radvila - N. Davics. God's Playground I (Oxford,1980).

"Silniaus Universitctas A.J. Grcimo Centro Studijos 3: Scmiotika 95: Prosper Meriméc. Lokys. Tckstas ir dvi interpretacijos (Vilnius,1995). For a general, account of Lithuanian bear kceping, sce R. Kicrsnowski. Akademia smorgonska i jej legenda, Kultura średniowieczna i staropolska. studia ofiarowane Aleksandrowi Gieysztorowi w pięsdziesięciolecie pracy naukowej (Warsaw, 1991), 595-603.

*The Author wishes to cxpress his gratitude to the Staff of the Prussian State Archive at Berlin for the opportunity to publish thesc documents, and especially to Dr Sven Ekdahl for assistance in obtaining copics of other manuscripts used in the writing of this article. 
geruche euwer genode zcu wissin, das ich vor euwern genoden habe geschrebin und noch schreibe, wy das dy obirsten Bayoren sint geczogen zcu holffe herczoge Segemonth und das merste teil des landes groß beqeren eynes fredes und sprechin, wer undir den czween herczog Swydirgal und herczoge Segemont dy land beholt gerne wellen wellen habin vor eynen hern, und dy Samaythen meynen keynen theile zcu helffen / konnen/ mit ganczer macht und ${ }^{\mathrm{b}} \backslash \mathrm{dy} / \mathrm{u} ß$ woren geczogen dy sint das merste heym komen, wen sy sich besorge der Kuwerlander und och zo habe ich zcithunge, das in VI tagen noch keyn Polen sy in Lyttauwen sunder sy solden $/$ mit/ VIII' pferden in korcz dar komen, und och genediger her homeister in den artickeln, dy mir euwer genode schrebit, wil uß lesen, das ich kan dirkennen, das den Samaythen notcze ist und do mitte ich meynen pfarrer in Samaythen wil senden zcu unsern wil lieben frunden, dy unserm orden und czu uns gancz sint geneyget, und zo sprechin dy Samaythen, sy wellen nicht krygen und ir meynunge ist alzo alzo ${ }^{c}$ ab herczog Segemond undirleyt euwer genode worde in villichte halden bis an sinen eyde, und des selbigen glich herczog Swydirgal und ab sy is mit dem herczen reden ader nicht dor ummb, zo wellen sy stylle sitczen.

Mynmel

Gegeben zcur Mymmel am freytag vor Lucie, Kompthur zcur

2

[1434], November 4, Memel

The Commander of Memel informs the Grand Master of developments in Lithuania concerning the nobles Rumbaudas, Jaunius, Sediboras, Kęsgaila and Vainutis.

A: Berlin, PKKA, OBA 6896 (formerly XVI.13), paper, no watermark, $30 \times 22 \mathrm{~cm}$, red seal under paper $(3.5 \mathrm{~cm}$ diameter $)$. Stain below text, hole in paper on lines six and seven.

Meynen garwilligen scholdigen, undertenigen gehorsam nu und zcu allengeczitten zcuvor. Erwirdiger, genediger, lieber herre homeister geruchet zcu wissin, das ich meynen besten und gewisten man von der Mymmel hatte gesant ken Samaythen mit goben zcu zcween bayorn bruder, dy eczlicher moße sint geneyget zcu unserm orden. Dy selbigen czwene bruder ich liß bitten zcu mir zcu komen alzo umb eyczliche heymlichenkyt mir zcu lutbaren. Zo ich euwern genoden vor habe gescreben mit zo waß der selbigen bayoren eyne mit ******** mane

"sic

"mit ganczer struck out

sic 
off komme und eyne mile geroten under des zo quam Kynzegal dynor von ****** und vorbotte alle kemerer off den hoff Kynzegal Krayßiene und der selbige bayore waß eyn kemerer eyne der obirsten von Samaythen, der nu muste keren und befuel meyne manne mir zcu sage, wy herczog Segemonth hette gefangen nonnen Rombolt, Schedebar hoptman von Kaywen, Jauwned, dy drye bruder und gebe in scholt, wy das sy in wolden vorraten, samm sy vorraten hetten herczog Swydergal und welden dy lande zcu eygen des koniges son von Polen. Das ander, das sy noch dem thode herczoge Wytholdis hetten abehandig brocht den schatez Wytholdis, zo das her eren eroperen noch dem lande wor komen zcu fromen. Sunder wy is noch, wer umb Kynzegal do von her mit keyne zcithunge noch brochte, unde der selbige bayor Waynothe mit sampt synem bruder mir haben lossin zagen, wy is her noch $\beta$ molß sich worde dirvolgen, das sy auch dirforsthin.

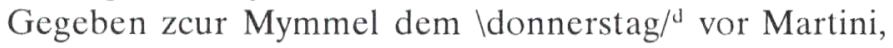
Kompthur zcur Mymmel 